\title{
The Determination of Phosphor Status in Leaf Tissues to Make a Fertilizer Recommendation and Predict Mangosteen Yield
}

\author{
Odit F. Kurniadinata1 ${ }^{*}$, Roedhy Poerwanto ${ }^{2}$, and Anas D. Susila² \\ ${ }^{1}$ Department of Agroecotechnology, Faculty of Agriculture, Mulawarman University, Samarinda, Indonesia. \\ ${ }^{2}$ Department of Agronomy and Horticulture, Faculty of Agriculture, Bogor Agricultural University, Bogor 16680, Indonesia \\ *Corresponding author: odit.ferry@gmail.com
}

\section{ARTICLE HISTORY}

Received: 11 July 2018

Revised: 27 July 2018

Accepted: 10 September 2018

\section{KEYWORDS}

\section{Xylem}

Leaf

Tissue analysis, Production

Flowers

\begin{abstract}
Mangosteen (GarciniamangostanaL.) knows as one of the most delicious fruit in the word, it's call as "Queen of fruits". The problems in mangosteen culture are low productivity and low fruit quality due to less developed technical culture, especially on fertilizer. There is a little information available on mangosteen fertilizer recommendation standards based on scientific experiment.Phosphor fertilizer increased growth especially in the generative stage of mangosteen. Phosphor increases the number of flowers and fruits set. It also decreases the number of flowers and fruits drop, with a linear response. It indicates mangosteen trees absorb phosphor to increase the vegetative growth and support production. Fertilizers increase phosphor concentrations in leaf tissues. Leaf tissues analyses showed the status of phosphor status, This status has a correlation to the yield. The higher the nutrients concentration in the leaf tissues, the higher the mangosteens yield in the next harvest.
\end{abstract}

This is an open access article under the CC-BY-SA license.

\section{INTRODUCTION}

Mangosteen (Garciniamangostana L.) is called as the Queen of Tropical Fruits. Mangosteen has a high economic value to be developed on a large scale (Poepenoe 1974; Cox 1988; Indriyani et al. 2002). Currently, mangosteen fruit is a major commodity in the export of Indonesian horticultural products to foreign countries. But the average mangosteen productivity in Indonesia is still low (Abdillah, 2008; Poerwanto, 2003; Liferdi, 2007). The important problem in the cultivation of mangosteen in Indonesia is the low production and quality of mangosteen. The high level of consumer demand for mangosteen fruit has not been followed by an increase in the maximum production of mangosteen. Of the total mangosteen production in Indonesia, only $7.8 \%$ included export quality (Poerwanto, 2000). While the low quality is related to the size of the fruit which is not uniform.

The low production and quality of mangosteen fruit are closely related to the availability of macro and micronutrients for mangosteen (Marschner, 1995). Fertilization techniques and doses of fertilizer are one of the main factors causing the low production of mangosteen in Indonesia (Safrizal, 2007). Most ofmangosteen plants in Indonesia are not currently fertilized, but only rely on nutrient supply from the soil. In addition, the technique of fertilizing mangosteen plants used is still not developed. There is a limitation on the latest information regarding proper fertilization techniques and doses of fertilizer because fertilization is done without scientific study or the results have not been proven scientifically.

Plant tissue analysis was carried out to determine the status of nutrients in the mangosteen plant tissues (Ryugo, 1988; Masrchner, 1995). Nutrient status in plant tissues also reflects the nutrient status in the soil. This technique can be the basis for determining the right dosage and fertilizer time. So there is a need for research to get more practical examples of mangosteen leaves but have a high level of correlation with mangosteen production. In this study determination of leaf samples based on trubus age and terminal leaf position on trubus is expected to be a more practical and appropriate method in determining the adequacy of mangosteen plant nutrients and predicting mangosteen production.

\section{MATERIALS AND METHODS}

The study was conducted in Cengal Village, Karacak, Kecamatan Leuwiliang, Kabupaten Bogor, Indonesia. The research location is located at an altitude of 390-398 m Above Sea Level (ASL). The study lasted for 13 months from preparation to data collection. The experiment was carried out using a Randomized Block Design (RBD), 
consisting of five levels of treatment with six replications. Each treatment level consists of one plant so that 30 productive mangosteen trees are needed (approximately 20 years of age and have fruited) that are relatively uni form in each experiment, phosphor Fertilization (P).

The dosage of $\mathrm{P}$ fertilizer consists of five levels, namely: without fertilizer P (P0); $300 \mathrm{~g} \mathrm{P}_{2} \mathrm{O}_{5}$ /plant/year (P1); 600 $\mathrm{g} \mathrm{P}_{2} \mathrm{O}_{5} /$ plant/year (P2); $900 \mathrm{~g} \mathrm{P}_{2} \mathrm{O}_{5} /$ plant/year (P3) and $1200 \mathrm{~g} \mathrm{P}_{2} \mathrm{O}_{5}$ /plant/year. Fertilization is given in three stages, the first stage is at the dormant stage (not flowering), as much as $20 \%$ of the dose specified; the second stage is given when it is approaching flowering stage (the beginning of the rainy season), as much as $60 \%$ of the dose specified; while the third stage was given when the mangosteen fruit diameter was about $2 \mathrm{~cm}$, as much as $20 \%$ of the dose specified. The provision of basic fertilizer is carried out in conjunction with the first stage of fertilizer application which is $600 \mathrm{~g} \mathrm{~N} /$ plant and $800 \mathrm{~g}$ $\mathrm{K}_{2} \mathrm{O} /$ plant/year.Leafsamplesbasedon fertilizer application time and harvest time.
Leaf samples taken from the four corners of plant growth (North, South, East, and West) with leaf criteria have reached maximum development. The number of samples was taken as much as 2 sheets for each corner. Leaf samples were taken in four stages, each stage of leaf sampling was as follows: before the first stage of fertilizer application; before the second stage fertilizer application; before the third stage fertilizer application; and after harvest.

\section{RESULTSAND DISCUSSIONS}

\subsection{Effect of Phosphorus Fertilization}

\subsubsection{Phosphorus content in leaves}

Phosphorus content in leaf tissue was observed four times as showed in Table 1.

Table 1. Phosphorus content in the terminal leaf tissue of mangosteen at four times observation.

\begin{tabular}{|c|c|c|c|c|}
\hline \multirow{2}{*}{ Phosphor (g) } & Dormant stage & Approaching flowering & Fruit diameterwas about $2 \mathrm{~cm}$ & Post-harvest \\
\hline & \multicolumn{4}{|c|}{$\%$} \\
\hline 0 & 0,05 & 0,07 & 0,09 & 0,07 \\
\hline 300 & 0,06 & 0,09 & 0,10 & 0,08 \\
\hline 600 & 0,06 & 0,12 & 0,12 & 0,08 \\
\hline 900 & 0,07 & 0,12 & 0,12 & 0,08 \\
\hline 1200 & 0,09 & 0,10 & 0,13 & 0,06 \\
\hline
\end{tabular}

Source: Laboratory of the Department of Soil Science and Land Resources, IPB.

Note:The phosphorus content of terminal leaves at post-harvest shows a relatively higher value when compared to the phosphorus content at the dormant stage

\subsubsection{Phosphorus Fertilization of Crop Productivity}

The application of phosphorus fertilization has an effect on several variables of plant productivity components observed, namely the number of flowers, the number of

Table 2. Effect of Phosphorus on the number of flowers, the number of flowers and fruit fall, the number of fruits harvested and fruit production/tree.

\begin{tabular}{|c|c|c|c|c|}
\hline $\begin{array}{c}\text { Phosphor Doses } \\
\text { (g/tree) }\end{array}$ & $\begin{array}{l}\text { The number of } \\
\text { flowers/tree } \\
\text { (Flowers) }\end{array}$ & $\begin{array}{c}\text { The number of flowers and fruit } \\
\text { fall/tree } \\
\text { (Flowers and Fruits) }\end{array}$ & $\begin{array}{c}\text { The number of fruits } \\
\text { harvested/tree } \\
\text { (fruits) }\end{array}$ & $\begin{array}{c}\text { Fruit } \\
\text { production/tree }(\mathrm{kg} / \text { tre } \\
\text { e) }\end{array}$ \\
\hline 0 & 90,33 & 26,33 & 64,00 & 5,64 \\
\hline 300 & 94,83 & 19,17 & 75,67 & 7,49 \\
\hline 600 & 105,33 & 20,33 & 85,00 & 8,94 \\
\hline 900 & 135,83 & 19,33 & 116,50 & 12,89 \\
\hline 1200 & 130,00 & 16,00 & 114,00 & 12,55 \\
\hline F-Test & $* *$ & tn & $* *$ & $* *$ \\
\hline Response patterns & $L^{* *}$ & $L^{*}$ & $\mathrm{~L}^{* *}$ & $\mathrm{~L}^{* *}$ \\
\hline
\end{tabular}

Note: $F$ test to see the mangosteen response to phosphorus fertilization; Response patterns are tested with orthogonal polynomials, $L=$ linear; ${ }^{*}=$ real at $5 \%$ test level; ${ }^{* *}=$ real at $1 \%$ test level; $t$ = not real. 
The availability of phosphorus for mangosteen plants affects the number of flowers and fruit produced, although it does not affect the number of flowers and fruit fall based on analysis of variance, there is a tendency that giving phosphorus decreases the number of flowers and fruit fall with linear response properties. A positive value for mangosteen fruit production. Percentage of flowers and fruit fall on the treatment without giving phosphorus fertilizer is $29.15 \%$, decreased to $12.31 \%$ in the treatment of giving phosphorus $1200 \mathrm{~g} /$ plant/year.

\subsubsection{Optimum dose of P fertilizer for mangosteen}

The results of the mangosteen plant showed a linear response to phosphor fertilizer application (Figure 1). These results indicate that the mangosteen plant has a positive response to phosphorus fertilizer with increasing crop yields.

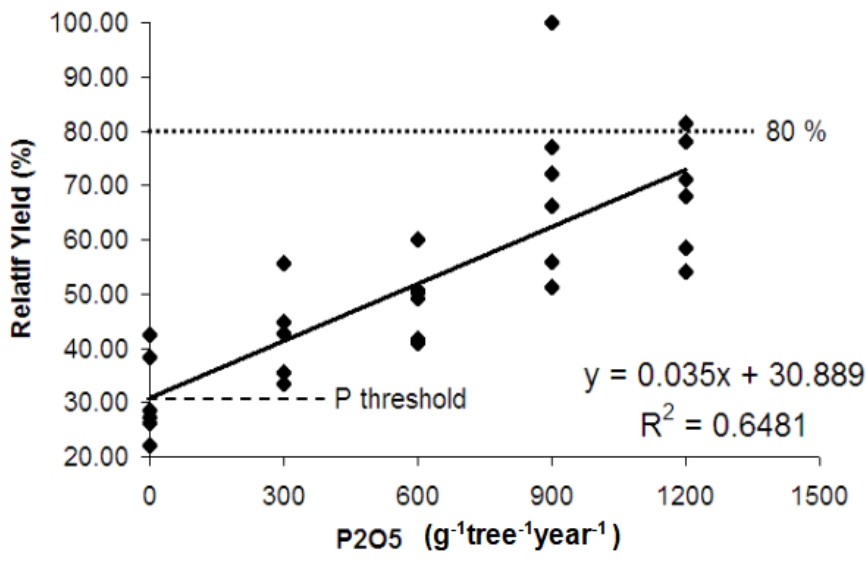

Figure 1. Relative yield of mangosteen fruit at Phosphor Fertilization

The response of the mangosteen plant is linear, so to determine the optimum fertilizer requirements for maximum production, the relative yield value of $80 \%$ is taken. Without phosphor fertilization application, the relative yield of mangosteen was $30,889 \%$ respectively.

\subsubsection{Recommendations for Phosphor fertilization on mangosteen plants}

This research showed that phosphorus fertilization application has an influence on the growth and production of mangosteen. However, to make a recommendation, a review of the economic aspects is needed, especially related to the price of fertilizer and the results that will be obtained by the mangosteen farmers. There are several alternative recommendations that can be made based on the relative yield data of mangosteen production.

Based on several alternative recommendations for phosphor fertilization on mangosteen that can be given, the best phosphor fertilization recommendation to get optimum results (80\%), need more than $1200 \mathrm{~g} \mathrm{P}_{2} \mathrm{O}_{5}$ / mangosteen tree/year (around $1400 \mathrm{~g} \mathrm{P}_{2} \mathrm{O}_{5} /$ mangosteen tree/year).

\section{CONCLUSION}

Phosphorus fertilization application has an effect on the components of mangosteen productivity. The results of the mangosteen plant showed a linear response to fertilizing treatment. This shows that the mangosteen plant has a positive response to phosphorus fertilizer with increasing crop yields. The best phosphor fertilization recommendations are on the optimum yield (80\%), is around $1400 \mathrm{~g} \mathrm{P}_{2} \mathrm{O}_{5} /$ mangosteen tree/year. The threshold value showed that without phosphor fertilization application, the relative yield of mangosteen plants was $30,889 \%$ respectively.

\section{REFERENCES}

Abdillah, M. 2008. Study of Nitrogen, Phosphorus and Potassium Fertilization of Mangosteen in the fourth production year.[Essay]. Bogor Agricultural Institute. Bogor.

Ashari, S. 1995. Horticultural aspects of cultivation.UI-Press. Jakarta.

Bernier, G., J.M.Kinet, R.M. Sachs. 2000. The Physiology of Flowering: volume 1, the initiation of flowers. CRC Press, Inc. Florida.

Cox. J. E. K. 1988. Garciniamangostana - Mangosteen. p. 361-375. In Gardner, R. J and S. A. Chaudori(eds.). The Propagation of Tropical Fruit Trees. FAO and CAB, England.

Indriyani, N.L.P., S.Lukitariati, Nurhadi and M. Jawal. 2002. Study of Mangosteen Damage due to Yellow Sap. Horticulture Journal. 12 (4): 276-283.

Liferdi. 2007. Diagnosis of Nutrient Status Using Leaf Analysis to Arrange Fertilization Recommendations on Mangosteen (Garciniamangostana L.). [Dissertation].Post Graduate School of Bogor Agricultural University. Bogor.

Marschner, H. 1995. Mineral Nutrition of Higher Plants.2nd edition.Academic Press. London.

Poepenoe, W. 1974.Manual of Tropical and Sub tropical Fruits.2nd book.Hafner Press. New York.

Poerwanto, R. 2000. Mangosteen cultivation technology. Paper presented at the Discussion of National Business and Technology of Mangosteen. Collaboration of the Tropical Fruit Study Center.LP-IPB with the Directorate General of Horticulture and Various Crops. Agriculture Department. Bogor.

Poerwanto, R. 2003. Teaching Materials for Fruit Cultivation.Module VII. Land Management and Fruit Garden Fertilization. Departement of Horticulture, Faculty of Agriculture. Bogor Agricultural University. Bogor.

Ryugo, K. 1988. Fruit Culture: its Science and Art. John Wiley and Sons, Inc. New York.

Safrizal. 2007. Study of Nitrogen, Phosphorus and Potassium Fertilization in Mangosteen in the third year of production. [Thesis].Post Graduate School, Bogor Agricultural University. Bogor. 